\section{Ervaringsgestuurd onderwijs.}

\section{Medisch onderwijs in de klinische werkplaats}

het steeds meer onder druk te staan tengevolge van toenemende aantallen studenten en specialismen, overwegingen ten aanzien van patiëntveiligheid en andere krachten. In dit proefschrift zijn de volgende onderzoeksvragen onderzocht:

1. Wat moet de student in de huidige studentgeoriënteerde klinische curricula in de klinische werkplaats leren?

2. Hoe moet de student in de klinische werkplaats leren?

In het onderzoek voor dit proefschrift is aandacht besteed aan de verticale integratie van het klinisch onderwijs tot vroeg in het curriculum. Met behulp van kwalitatief focusgroeponderzoek en een systematisch literatuur review is gepoogd inzicht te verwerven in de onderbouwing van het invoeren van klinische ervaringen vroeg in het curriculum. Uit dit onderzoek kwam naar voren dat deze curriculumontwikkeling een afspiegeling vormt van een socio-cognitieve benadering van klinisch onderwijs waarbij de professionele socialisatie van de student en de ontwikkeling van de eigen professionele identiteit een belangrijke rol spelen.

Vervolgens richtte het onderzoek zich op het leren in de klinische werkplaats vanuit het standpunt van de docent, de student en de interactie hiertussen. Hiertoe is gebruik gemaakt van een fenomenologische benadering, onderzoek op basis van grounded theory en 'designbased' onderzoek. Ook is een innovatieve technologie voor onderwijsorganisatie getest. Opnieuw kwam uit de resultaten het uitgesproken sociale karakter van het onderwijs in de klinische werkplaats naar voren. De onderwijsbenadering op basis waarvan probleemgestuurd onderwijs was ingevoerd (waarbij de nadruk sterker ligt op de autonomie van de student dan op de expertise van de clinicus) bleek afstand gecreëerd te hebben tussen docenten en 
Naam

Opleiding

Klinische

specialisaties

Onderzoeksgebieden

Huidige functies
Tim Dornan Unopleiding: Oxford University (UK) en University of Washington (Seattle, USA) Algemene interne geneeskunde, diabetes, endocrinologie.

Onderwijs in de klinische werkplaats Toepassing van ICT in het onderwijs in de klinische werkplaats

Carrièrekeuzes van artsen in opleiding Fitness for purpose en postinitiele opleiding Professor of Medicine and Clinical Education, University of Manchester, en Director of Medical Education Honorary Consultant Physician, Salford Royal NHS Foundation Trust studenten. Ter overbrugging van deze afstand moest nieuw onderwijs ontwikkeld worden.

In het laatste deel van het proefschrift zijn nieuwe beoordelingsmethoden voor het klinisch onderwijs onderzocht die valide uitkomstmetingen kunnen bieden als aanvulling op summatieve beoordelingen. Opnieuw onderstreepte het onderzoek het sociale karakter van het klinisch onderwijs (met onderwijsklimaat als een belangrijk construct).

Aan het eind van het proefschrift zijn de bevindingen uit de eerdere hoofdstukken samengebracht en geïntegreerd in een model voor ervaringsgestuurd onderwijs. 